Leo Catana, 'Readings of Platonic Virtue Theories from the Middle Ages to the Renaissance'

The Case of Marsilio Ficino's De amore

\author{
Catana, Leo
}

Published in:

British Journal for the History of Philosophy

DOI:

10.1080/09608788.2014.952619

Publication date:

2014

Document version

Peer reviewed version

Citation for published version (APA):

Catana, L. (2014). Leo Catana, 'Readings of Platonic Virtue Theories from the Middle Ages to the Renaissance': The Case of Marsilio Ficino's De amore. British Journal for the History of Philosophy, 22(4), 680-703. https://doi.org/10.1080/09608788.2014.952619 


\title{
Readings of Platonic Virtue Theories from the Middle Ages to the Renaissance:
}

\author{
The Case of Marsilio Ficino's De amore
}

\section{By Leo Catana}

\section{British Journal for the History of Philosophy 22.4 (2014) (preprint)}

\begin{abstract}
It is commonly known that ancient schools of ethics were revived during the Renaissance: The texts pertaining to Platonic, Aristotelian, Stoic and Epicurean ethics were edited, translated and discussed in this period. It is less known that the Renaissance also witnessed a revival of Plotinian ethics, by then perceived as a legitimate form of Platonic ethics. Plotinus' ethics had been transmitted through the Middle Ages through Macrobius' Latin treatise In somnium Scipionis I.8, which relied heavily on Plotinus' student, Porphyry, and his report of Plotinus' ethics. In this article it is argued that the Florentine humanist and philosopher Marsilio Ficino carried on this tradition of Platonic, or rather Plotinian, ethics. He was familiar with Plotinus' Enneads, since he had had access to it through Greek manuscripts from around 1462; his Latin translation of the Enneads was published in 1492. The article argues that in his commentary on Plato's Symposium, completed in 1469, Ficino made use of Plotinian ethics and bypassed the monastic interpretation, which Plotinian virtue ethics had received from medieval theologians and philosophers. Ficino thus re-interpreted the Plotinian theory in a more worldly manner, making the so-called "higher virtues" accessible to humans outside religious institutions, attained by their natural constitution.
\end{abstract}


Keywords: Platonic virtue ethics, Renaissance ethics, Plotinus, Thomas Aquinas, Marsilio Ficino.

\section{Introduction}

Ethical virtue was a key term in the argumentative structure of Plato's Symposium, dedicated to the theme of love, or eros: as proposed by the first speaker, eros (erôs) provides ethical virtue (aretê) and happiness (eudaimonia). ${ }^{1}$ Accordingly, several of the following speakers discuss the notion of ethical virtue. ${ }^{2}$ For this reason, Marsilio Ficino (1433-1499) discussed ethical virtue in his commentary, De amore, completed in 1469 and published in 1484 along with his Latin translations and commentaries on Plato's collected dialogues and letters. In his commentary, Ficino elucidated the notion of ethical virtue in Plato's dialogue by drawing on ethical theories among late ancient Platonists such as Plotinus (204/5-270 CE), Porphyry (234?-305? CE) and Macrobius ( $5^{\text {th }}$ century CE), which were known in late medieval philosophy through Macrobius' In somnium Scipionis I.8. Ficino had gained access to Plotinus' Enneads in 1462 via one or possibly two manuscripts

1 Plato, Symposium 180b6-8. I owe thanks to Michael J. B. Allen, Christopher S. Celenza, Anna Corrias, Dilwyn Knox and Jill Kraye for their respective papers and comments to my paper on Ficino's ethics, presented at a workshop on virtue ethics and Renaissance Platonism, held in October 2012 at the University of Copenhagen. I would also like to thank Denis Robichaud and James G. Snyder for commenting on early drafts to this article.

2 For 'virtue' in Plato's Symposiun and Ficino's De amore, please see the Appendix. 
(Laurentianus 87,3 and Parisinus graecus 1816). ${ }^{3}$ In 1492, he published a Latin translation of the Enneads, and he wrote extensive commentaries on Enneads I, II, and III, and less extensive ones on Enneads IV, V, and VI. This meant that Ficino commented upon the two treatises that were key to Plotinus' virtue theory, namely Ennead I.2 (On virtues) and I.4 (On happiness). ${ }^{4}$ I argue that this late ancient Platonic tradition was significant to the theories about ethical virtue advanced in De amore.

De amore was composed when Ficino was about 36 years old, and its ethical themes were dealt with in his other Plato commentaries (e.g. those for the Gorgias, Republic and Laws), in his Plotinus commentaries, and in his Theologia platonica. So why focus on ethics in De amore? There are three reasons for this. First, De amore, composed as a dialogue where five characters emulate the seven speakers in Plato's Symposium, is congenial to Ficino's ethics, as he explains it in a letter of his; imitation of honorable exempla provides a more effective moral training than abstract theorizing. None of his other Plato commentaries is composed as a dialogue. Second, the five characters in De amore consist of intellectuals and poets with an interest in Platonism, and they represent historical persons in contemporary, civic Florence; this literary setting illustrates one key point in Ficino's ethics, namely that the acquisition of the supreme good is not exclusive to saints or those living a monastic life, but potentially possible to all human beings due to their natural constitution. Third, De amore is a thematically comprehensive and relatively independent text that is less closely keyed to its themes in the pretext, the Symposium, than most of his

3 On the two manuscripts consulted by Ficino, see Saffrey, 'Florence, 1492: The Reappearance of Plotinus', 490-491. See also Wolters, 'The First Draft of Ficino’s Translation of Plotinus', 305-29; Wolters, 'Ficino and Plotinus' Treatise On Eros', 189-197.

4 Ficino, In Plotinum I.2 and I.4, pp. 7-11, 22-8. 
other commentaries to still other Plato dialogues. This is philosophically important, because it allows Ficino to state his own view in a more synthetic manner. The comprehensive nature of De amore allows Ficino to connect two philosophical categories that are central to his ethics, namely cognitive and ethical ones. According to Ficino, the early fall of man meant that man's higher cognitive faculty had been lost. This faculty could be regained by assimilating certain ethical virtues. Ficino turned to late ancient Platonists, Plotinus in particular, for clarification of these ethical virtues. However, Ficino scholars have paid little attention to Ficino's use of this ancient tradition.

\section{Studies on Ficino's Use of late Ancient Platonic Ethics}

In 1923, Giuseppe Saitta claimed Ficino's indebtedness to a Plotinian virtue theory in his De amore, though without explaining how Ficino made use of this ethical tradition. ${ }^{5}$ After Saitta, we find two dismissive attitudes to this ethical component in this work of Ficino.

One attitude is theological and advanced by Walter Dress in 1929. Like Saitta, he noted the presence of Plotinian virtue ethics in Ficino's philosophy, but he condemned it with unrestrained Protestant bias: Virtue theory should not replace the lex evangelica and the sola fide gratiaque. ${ }^{6}$ To Dress, the Plotinian, ethical element in De amore became entangled in a contemporary polemics between Catholicism and Protestantism, where

\footnotetext{
5 Saitta, La filosofia di Marsilio Ficino, 268-9.

6 Dress, Die Mystik des Marsilio Ficino, 210-14.
} 
Plotinian ethics came to be seen as Catholic and therefore unacceptable to Protestants like Dress. $^{7}$

Another dismissive attitude to the ethical component in Ficino's thought is methodological and advanced by Paul Oskar Kristeller (1905-99). His familiarity with Plotinus' ethics is evident in his early study published in 1929, Der Begriff der Seele in der Ethik des Plotin. There, however, he did not discuss the concepts, theories and arguments in Plotinus' Ennead I.2, or indeed the medieval tradition for Platonic ethics, transmitted via Macrobius; instead, he reduced Plotinus' ethics to two levels, that of the higher self with its metaphysical consciousness ("metaphysische Bewußtsein") and that of the lower self with its orientation towards an empirical world (“die gegenständliche Wirklichkeit”). Thereby Kristeller provided, as he explains, a Kantian interpretation of Plotinus, regarding Plotinus as the origin of the Kantian subject-object antagonism. ${ }^{8}$

7 Dress' view did not come out of the blue. In 1699, the orthodox Lutheran Christian Friedrich Bücher (1651-1714) had reported the Porphyrian doctrine of the four levels of virtue (the civic, purgatory, the contemplative and the paradigmatic), referring the doctrine to Plato (Plato mysticus in pietista redivivus, 30). (In fact, it is not found in Plato's works, but in Porphyry's Sententiae 32.) To Bücher, this virtue theory makes up an integral part of the detestable theory of the Platonists who hold that the human soul can be united with the divine. Ibid.,135, Bücher held that only grace, not intellect and will, unifies the soul with the divine. Bücher's position was indicative to subsequent German Lutherans; see Catana, 'Thomas Taylor's Dissent'.

$8 \quad$ Kristeller, Der Begriff der Seele in der Ethik des Plotin, 11-12. Ibid., 20, he says: "Es ist das Ziel der folgenden Untersuchung, das metaphysische Bewußtsein als Sinn und Schlüssel der eigentlichen Ethik Plotins zu erweisen.” Ibid., 57, he connects the higher virtues in Plotinus to the metaphysical consciousness ("metaphysische Bewußtsein"). The young Kristeller was influenced by Neokantians, e.g. Ernst Hoffmann, who believed that Plato and later ancient Platonists could be assimilated to Kantian 
This reductionistic approach is puzzling. Kristeller was familiar with Lieshout's 1926 study of Plotinus' virtue theory - one of the earliest studies that had dealt with the specifics of Plotinus' virtue theory in Ennead I.2, and one in which Porphyry's, Macrobius' and Augustine's transmission of Plotinus' virtue ethics in late scholasticism had been explained and documented. In his 1929 study, Kristeller rejected Lieshout's study tout court: "there is little to be learned" from this and similar studies, he stated. ${ }^{9}$ Porphyry's rendering of Plotinus' virtue ethics, consisting of four levels of virtues, according to Porphyry, did not represent Plotinus' position adequately, Kristeller argued. ${ }^{10} \mathrm{He}$ regarded Porphyry's transmission of Plotinus' virtue theory as irrelevant to an understanding of Plotinus' ethics, even though Porphyry and Macrobius held the four-level theory to be an adequate account of Plotinus' virtue ethics in Ennead I.2, and even though this interpretation remained influential in the Middle Ages and the Renaissance. Plotinus scholars largely rejected Kristeller's 1929 study and its reduction of Plotinus' ethics to two

philosophy; see Hankins, "Kristeller and Ancient Philosophy”, 131-5. In 1979, Kristeller declared himself "an old Kantian" ("The Place of Ethics in Renaissance Thought”, 172).

9 Kristeller, Der Begriff der Seele in der Ethik des Plotin, v: “...wenig zu entnehmen...”. Ibid., v, n. 4, Kristeller refers explicitly to Lieshout, La théorie Plotinienne de la vertu. In this work Lieshout explains Plotinus' virtue ethics and its place in the Platonic tradition (56-87), its interpretation in the thoughts of Porphyry, Psellus, Augustine and Macrobius (88-122), and its reception in scholasticism, e.g. Albert the Great, St Bonaventure and Thomas Aquinas (123-80).

${ }_{10}$ Kristeller, Der Begriff der Seele in der Ethik des Plotin, 56-7. Ibid., 56 n. 1, he says: "Plotin kennt in Wahrheit nur diese zwei Stufen der Tugend [i.e. higher and lower virtues]. Die Vorstellung von vier Tugendgraden geht auf Porphyrius zurück (sententiae Nr. 32), trifft jedoch für Plotin nicht zu....”. 
levels of the self, mainly on the ground that it was too schematic - the Plotinus scholar Paul Henry thus characterized it as pure construction. ${ }^{11}$

In the 1929 study Kristeller identified two schools in Plotinus scholarship: One school holds that Plotinus' ethics is deducible from his system of philosophy, implying that Plotinus' ethics itself was less important than the overarching principles in Plotinus' system. The $19^{\text {th }}$-century historian of philosophy Eduard Zeller (1814-1908) is listed as an exponent of this school. The other school regards Plotinus' ethics as a form of religious experience, preparing for religious ecstasy; this implies that the philosophical content of Plotinus' ethics is lost. René Arnou's Le désir de Dieu dans la philosophie de Plotin, published in Paris in 1921, is counted as an example of this second school. ${ }^{12}$ Kristeller placed himself within the first school, since he contended that we find a system of philosophy implicit in Plotinus' texts. ${ }^{13}$ Kristeller's methodological position may explain why he was unwilling to enter the details about Plotinus' virtue theory in his 1929 study: virtue ethics, as presented in Ennead I.2, must be understood against the background of Plotinus' system, whose foundation is of a metaphysical nature.

Kristeller probably had the best intentions when approaching Ficino as a system builder. German historians of philosophy since the age of Jacob Brucker (1696-1770) had

11 For Henry’s assessment, see Blum, “The young Paul Oskar Kristeller as a Philosopher”, 24.

12 Kristeller, Der Begriff der Seele in der Ethik des Plotin, iii-iv. For the system concept in $19^{\text {th }}$-century general histories of philosophy, see Catana, The Historiographical Concept 'System of Philosophy', 195260.

13 Kristeller, Der Begriff der Seele in der Ethik des Plotin, 3, 16. In his early lectures on Hellenistic philosophy, Kristeller similarly referred approvingly to the histories of philosophy written by Überweg, Zeller and Windelband; see Kristeller, Filosofi greci dell'età ellenistica, 148. 
required from a genuine philosopher that he expounded a system of philosophy, and a historian of philosophy would typically vindicate a past thinker's worth as a philosopher on this premise; Kristeller's compatriot Ernst Cassirer (1874-1945) had provided this service for Giovanni Pico della Mirandola (1463-94) in the 1940s. ${ }^{14}$ Kristeller intended to rehabilitate Ficino's philosophy precisely on this premise. The main problem is that the premise is false: Pre-enlightenment philosophers did not intend to develop systems of philosophy, and it is therefore misleading to reconstruct their output as systems, that is, axiomatic-deductive complexes of philosophical theories deduced from a few general metaphysical theories, so-called principles. This premise was an anachronistic claim introduced by Brucker but successfully implemented into the methodology of subsequent histories of philosophy, including that of Eduard Zeller and Kristeller. ${ }^{15}$ Kristeller's erroneous reconstruction of Ficino's philosophy does not mean, of course, that Ficino was worthless as a philosopher, only that his worth must be argued for on other grounds.

Kristeller was loyal to this methodological view in his monograph on Ficino, originally composed in German in the 1930s, published in an English version in 1943, an Italian version in 1953, and, finally, a German one in 1972. His methodological view implied that his overall intention was to present Ficino's system of philosophy as it was

14 Kristeller, The Philosophy of Marsilio Ficino, 410, praises Cassirer's article 'Giovanni Pico della Mirandola'. In this article (128), Cassirer had reported Brucker's claim that Pico was guilty of syncretism (stated in Brucker, Historia critica philosophiae, vol. 4, 60). Cassirer intended to vendicate Pico's philosophy on the ground that it did contain a complete and coherent system.

15 Catana, The Historiographical Concept 'System of Philosophy'; id., 'Changing Interpretations of Plotinus'. 
implicit in what he took to be Ficino's major work, the Theologia platonica ${ }^{16}$ Given his methodological assumption, Kristeller failed to identify Ficino's ethics within the over-all system. ${ }^{17}$ Hence, the virtue ethics of Plotinus, Porphyry and Macrobius were dealt with offhandedly. ${ }^{18}$ Although Kristeller's methodology is problematic, his observations on Ficino's notions of interiority, psychology and epistemology remain important. What is of relevance to this article is, however, that Kristeller's methodology implied that he did not take full account of the late ancient Platonic tradition, especially Enneads 1.2 and I.4, in his interpretation of Ficino's ethics.

As regards De amore, Kristeller did discuss Ficino's intervention into the willintellect controversy, which has an ethical element to it, but without pointing out the significance of Platonic virtue ethics, and its Plotinian components. ${ }^{19}$ In general, Kristeller seems to have been unaware of the role of Macrobius as an indirect source of Plotinus'

16 For Ficino's system, see, for instance, Kristeller, The Philosophy of Marsilio Ficino, 4-9, 37, 92, 121, 139, $146,171,203,212,255-7,285,287,324,346$.

17 Kristeller expected to find a "system of morals" (ibid., 289, 316) and a "system of aestehetics" (304) in Ficino's philosophy, but could not find either; this failure was probably due to Kristeller's anachronistic expectations rather than to Ficino's philosophy.

18 Ibid., 289-94. For a similar derivative treatment of ethics in Plotinus' philosophy, see id., "The Place of Ethics in Renaissance Thought", 168. In "Francesco da Diacceto and Florentine Platonism in the Sixteenth Century", 311-2, however, Kristeller does observe that in Francesco da Diacceto's commentary on the two first speeches of the Symposion (composed no later than 1519), noetic ascent was marked by degrees of virtue, as explained by Plotinus. This observation, however, did not lead Kristeller to look out for Plotinian ethics in Ficino's De amore, although it is well known that Ficino influenced Diacceto's Platonism.

19 Id., “A Thomist Critique of Marsilio Ficino’s Theory of Will and Intellect”, for instance, does not relate Ficino's virtue ethics to the will-intellect debate. 
ethics in the late Medieval and Renaissance period. ${ }^{20}$ Hence, the role of late ancient Platonic ethics to Ficino's De amore, and perhaps in his philosophy in general, needs further examination.

\section{Late Ancient Platonist Texts in The Middle Ages and the Renaissance}

Given the historiography of Ficino's philosophy, I now turn to the following question: How were late ancient Platonic ethics transmitted prior to Ficino? Plotinus' Ennead I.2 and Ennead I.4 are of particular interest to Plotinus' virtue theory, but Ennead I as a whole is highly relevant. Unfortunately, the Enneads were not translated into Latin in late antiquity, possibly with the exception of some passages that might have been translated by Victorinus $\left(4^{\text {th }}\right.$ century CE) and possibly read by St Augustine (354-430 CE); if they ever existed, these early Latin translations were lost in the early Middle Ages.

Plotinus' student and editor, Porphyry, used Ennead I.2 as a starting point for his highly systematized account of the virtues in his Sententiae 32. Porphyry argued that the four cardinal virtues should be understood within a continuum of four levels, namely on a civic, a purificative, a contemplative and a paradigmatic level: we find all four cardinal virtues on each of these four levels. ${ }^{21}$ Plotinus had accepted Plato's distinction between 'civic virtues' (politikai aretai) and 'greater virtues' (meizônes aretai), and this distinction

20 Kristeller, “The Place of Ethics in Renaissance Thought", 169-71, ignores Abelard's and Aquinas' uses of Marobius' account of Plotinus' ethics.

21 Porphyry, Sententiae 32, ed. Brisson, 334-44. For Porphyry's ethics and its relationship to that of Plotinus, see Brisson, "The doctrine of the degress of virtues in the Neoplatonists"; Karamanolis, "Transformations of Plato’s Ethics'; Emilsson, 'Porphyr'. 
was picked up by Porphyry. ${ }^{22}$ Still, Porphyry's theory of ethical virtues marks a development of Plotinus' theory. Ficino made a Latin translation of Porphyry's Sententiae in 1488 and published it in 1497, five years after his publication of Plotinus' Enneads, and two years before his death. Ficino entitled the text De occasionibus sive causis ad intelligibilia nos ducentibus. It is not known which manuscript(s) Ficino used for his translation, though it is likely that he used the MS Laurenziana $80.15 .^{23}$ The translation was incomplete: it did not include sententiae 9, 14, 29, 32-44. ${ }^{24}$ Hence, the ethically significant sententia 32 was left out: in this passage Porphyry had interpreted each of the four cardinal virtues on four levels, namely the political, the purificative, the intellective and the paradigmatic level.

Macrobius' Latin work, In somnium Scipionis I.8.1-13, provided a Platonic theory of ethical virtues. In I.8.5 he refers explicitly to Plotinus' "book of virtues" (liber de virtutibus), that is Ennead I.2, as his guide. Macrobius may have wanted to state his loyalty to the conceptual scheme in Plotinus' Ennead I.2, although he in fact relies on the account of the various virtues and levels of virtues given by Porphyry's Sententiae 32.

This Latin work of Macrobius had an important influence in the Middle Ages through a rich manuscript tradition. It was unique, since it provided an ancient, late Platonic

22 For the distinction in Plotinus, see his Enneads I.2.1.22 and I.3.3.2.

23 This has been suggested in Gentile, Niccoli and Viti (eds), Marsilio Ficino e il ritorno di Platone, 122-3. I owe this reference to Denis Robichaud.

24 For Ficino’s translation of Porphyry's Sententiae, see Flamand, “Éditions et traductions des AФOPMAI de Porphyre", 285-6. For the date of Ficino’s translation, see Ficino, Supplementum, ed. Kristeller, vol. 1, CXXXV. 
ethical theory that was unmediated by Augustine or other Christian thinkers. ${ }^{25}$ Peter Abélard (1079-1142), for instance, refered to Macrobius' account of the virtues in I.8.1-13, believing that the theory ultimately belonged to Plotinus. ${ }^{26}$ Another case is Thomas Aquinas (1225-74). ${ }^{27}$ Aquinas presented a thorough discussion of ethical virtue in his Summa theologiae 1a2ae, questions 55-67. In questions 55-60 he largely followed Aristotle's Ethics in its definition of ethical virtue and the distinction between moral and intellectual virtues. In question 61, article 5, he breaks up this account, stating that so far he has only been discussing man as a "political animal" (animal politicum); from question 61 article 5 resp. onwards, he discusses man as far as he strives for divine things, referring to Aristotle's Ethics X.7 and Matthew 5.48 as his authorities.

Aquinas argues that this striving for divine things must be directed towards God, for which reason there must be virtues in God on which human beings can model their virtues. ${ }^{28}$ In order to bridge the chasm between the virtues pertaining to man as a political and social being and man as a being striving to become similar to God, Aquinas embraces "Plotinus" virtue theory in Ennead I.2 as it was reported in Macrobius' In somnium Scipionis I.8: Aquinas accepts the idea of "exemplary virtues" in God, and he accepts the idea that there are two intermediary levels of virtue between the political virtues, pertaining

25 For the manuscript tradition in the Middle Ages, see Armisen-Marchetti, "Introduction", LXXIILXXXVIII. For Macrobius' influence in the Middle Ages, see Zintzen, "Bemerkungen zur Nachwirkung des Macrobius in Mittelalter und Renaissance".

26 Abelard, Theologia christiana II.64-5, pp. 157-8. I owe this reference to Simo Knuuttila.

27 For Aquinas' use of late Platonic virtue theory, see Hochschild, "Porphyry, Bonaventure and Thomas Aquinas"; Inglis, 'Aquinas's Replication of the Acquired Moral Virtues'.

28 Aquinas, Summa theologiae 1a2ae qu. 61 art. 5, resp., pp. 130-2. 
to man as a political animal, and God's exemplary virtues, namely the "purifying virtues" (virtutes purgatoriae) and the "virtues of the soul already purified" (virtutes iam purgati animi). The former denote the virtues found in men striving to become similar to God but who have not yet arrived: these are prudence (looking at the things of God, scorning the things of this world), temperance (setting aside the needs of the body as far as nature allows), courage (preventing the soul from being afraid of losing the body in its approach to the divine) and justice (the soul being dedicated to follow the course thus resolved). In regard to the latter, the "virtues of the soul already purified", Aquinas stipulates: "prudence sees only the things of God; temperance knows no earthly desires; courage is immune from passion; and justice, by imitating the divine mind, is united to it in an everlasting union." 29 This is the life of the blessed in this life, who live without passions and who withdraw from human affairs, dedicate themselves to learning and contemplate truth. ${ }^{30}$ This accommodation of Plotinus' ethics prepares the introduction of the theological virtues in question 62. In questions 63-7, Aquinas discusses the cause of virtues and their internal connection, and he compares the virtues and their duration in and after this life.

In this context Aquinas introduces the 'infused virtues' (virtutes infusae) in opposition to the 'acquired virtues': All virtues are not simply virtues internalised through habit, that is, acquired virtues, since there are virtues which are infused by God, that is, virtues in us that are operative in us because of God. ${ }^{31}$ Whereas the acquired virtues make men behave well in human affairs, the infused ones make men behave well in regard to

\footnotetext{
29 Ibid., 1a2ae qu. 61 art. 5 resp., p. 132.

30 Ibid., 1a2ae qu. 61 art. 5 con. 3 , p. 132.

31 Ibid., 1a2ae qu. 55 art. 4 resp., p. 14.
} 
divine things. ${ }^{32}$ Finally, Aquinas introduces the theological virtues, that is, faith, hope and charity: These virtues transcend human virtues (that is, acquired and infused), since they simply make men take part in divine grace $($ gratia $) .{ }^{33}$

Ficino is likely to have known this accommodation of Macrobius' rendering of Plotinus' ethics, but his familiarity with Plotinus' authentic sources and his distinct philosophical view meant that he did not follow Aquinas on this point in his De amore. The technical term used by Aquinas, 'infused virtues', is absent in the ethically significant passages of De amore, and so are the theological virtues. ${ }^{34}$ In De amore, Ficino used the notion of 'infused light' (lux infusa) in ethically important passages, as we shall see below, but this notion differs from Aquinas' technical and therefore identifiable notion of 'infused virtue'. The notion of 'infused light', on the other hand, was widely used within the Platonic tradition and not easy to pin down on any particular author. ${ }^{35}$

In the $15^{\text {th }}$ and $16^{\text {th }}$ centuries, In somnium Scipionis came out in at least 22 different editions (editio princeps 1472, Venice), typically in Italy and France, and always printed together with Macrobius' Saturnalia. ${ }^{36}$ Ficino owned a manuscript with In somnium

32 Ibid., 1a2ae qu. 63 art. 4, resp. and con., pp. 160-2. For the role of this notion in Aquinas' ethics, see Inglis, 'Aquinas’s Replication of the Acquired Moral Virtues'.

33 Aquinas, Summa theologiae 1a2ae qu. 62 art 1-4, pp. 136-148; ibid., 1a2ae qu. 58 art. 4 con. 3 , p. 72.

34 Cf. Jayne's note in Ficino, Plato's Commentary on Love, IV.5, p. 77 n. 15 (d); he claims that Ficino accommodated Aquinas' idea of infused virtues in De amore IV.5.

35 For a parallel use of $l u x$ in an ethical context, see Ficino, "Argumentum de summo bonum", 96-7. For the notion of light in Ficino's thought, see Scheuermann-Peilicke, Licht und Liebe. Lichtmetapher und Metaphysik bei Marsilio Ficino.

36 For printed editions in the 15th and 16th centuries, see see Armisen-Marchetti, "Introduction", LXXXVIII-LXXXIX. For the influence of In somnium Scipionis in the Renaissance, see ibid., LXXI; 
Scipionis (Firenze, Biblioteca Riccardana, 581): it had served him as one of the Latin introductions to the platonici in his early years, well before he began to learn ancient Greek in the late 1450s. ${ }^{37}$ After he had learned Greek, Ficino was thus able to go back to the ultimate source of Macrobius' ethical theory in In somnium Scipionis I.8, namely Plotinus' Ennead I.2, through most of his career, and he used this tradition in different ways. However, he still affirmed Macrobius' version in his Theologia platonica of $1482 .{ }^{38}$

This cluster of texts by Plotinus, Porphyry and Macrobius, and in particular the passages on ethics signalled above, provided important sources to Ficino's commentary on Plato's Symposium, completed in 1469. At that point in time, Ficino had been familiar with Plotinus' virtue theory for more than a decade through Macrobius' account; he had had access to Plotinus' Enneads in Greek for seven years, namely since 1462. It is more difficult, however, to date his first acquaintance with Porphyry's Sententiae.

Ficino acknowledged four schools in ancient Greek philosophy — the Platonic (i.e. the Academy), the Aristotelian, the Epicurean and the Stoic — and he pinpointed the soul's

Zintzen, "Bemerkungen zur Nachwirkung des Macrobius in Mittelalter und Renaissance”; Hankins, Plato in the Italian Renaissance, 839.

37 For Ficino's manuscript, see Gentile, Niccoli and Viti (eds), Marsilio Ficino e il ritorno di Platone, n. 3 , pp. 3-4. For the period in which Ficino learned Greek, see Vasoli, 'Ficino, Marsilio', 378-80. For Ficino’s use of Macrobius, see Zintzen, "Bemerkungen zur Nachwirkung des Macrobius in Mittelalter und Renaissance", 428-31.

38 Ficino, Theologia platonica XIV .6, eds Hankins, Bowen et alii, vol. 4, 266. Cf. Macrobius, In Somnium Scipionis I.8.5. 
likeness with the divine as the essence of the Platonic school. ${ }^{39}$ In this school he included late Platonists like Plotinus, Porphyry and Macrobius as legitimate heirs who had carried on the Platonic idea of divine likeness, and this feature similarly stands out when Ficino presents the Platonic version of virtue ethics in De amore. ${ }^{40}$

\section{Ficino as a Moral Philosopher}

Philosophical theories are not a function of availability of texts. So, how did Ficino conceive of ethics, and how could he possibly make use of late ancient Platonic ethics in his De amore? In an early, undated letter, Ficino doubted the value of ethical theorizing: it is more effective to emulate honourable exempla (imitatio) than to pursue philosophical reading and speculation (lectio), even when reading the greatest ancient thinkers. ${ }^{41} \mathrm{De}$ amore was to some extent modelled on this view: The protagonists are "bearing the mask" (personam gerere) of ethically superior figures in Plato's Symposium, and the "virtue

39 For these four schools, see Ficino, "De quatuor sectis philosophorum", 7. For divine likeness as an essential feature of the Platonic school, see ibid., 8, and id., "De virtutibus moralibus", 5-6. For the Platonic idea of divine likeness, see id., De amore VII.13, ed. Laurens, 239.3-4 [ed. Marcel, 257.3-4]; id., Theologia platonica XIV.10, eds Hankins, Bowen et alii, vol. 4, 318; id., Epistulae 50, 115, 123, ed. Gentile, 97, 207, 226-7.

40 For this idea in Plato, see his Theatetetus 176a-b; Phaedrus 247e-248a, 253b-c; Phaedo 69c-d. The idea of divine likeness is cited in Alcinous, Didaskalikos 28, ed. Whittaker, 56; Plotinus, Ennead I.2.1; Porphyry, Sententiae 32.32, ed. Brisson, 336; Macrobius, In somnium Scipionis I.8.3, ed. Armisen-Marchetti, 50. Kraye, "Moral Philosophy", 350-1, accounts for this idea in Ficino, though without going into the tradition of late ancient Platonic virtue ethics and its use in Platonic ethics in the Renaissance (ibid., 349-64).

41 Ficino, Epistulae 3, ed. Gentile, 11. In Ficino's Plato biography (De vita Platonis), we similarly find mimetic elements, as pointed out in Robichaud, 'Marsilio Ficino’s De vita Platonis', 32-3. 
theory" that we find in this work is not presented in the form of philosophical treatises structured according to a conception of the highest good, or indeed according to a system, but within such a model of emulation. ${ }^{42}$

Ficino composed two short ethical texts, which were independent of classical texts (e.g. Plato's Philebus or Plotinus' Ennead I.2 and I.4), namely “De quatuor sectis philosophorum" and "De virtutibus moralibus", both composed in $1457 .{ }^{43}$ In the firstmentioned text he sets out four ancient schools - Academics (i.e. Platonists), Peripatetics, Stoics and Epicureans - and he explains their different conceptions of the highest good (summum bonum) as one of the distinguishing features. To Platonists the highest good is to achieve divine likeness; to Peripatetics, who cannot agree among themselves whether the human soul is mortal or immortal, the highest good consists in perfect and virtuous action; the Stoics hold that the highest good consists in living in accordance with our inner virtue, and that the virtues imply each other mutually; the Epicureans hold that the highest good consists in pleasure (voluptas), which includes not only corporeal pleasure but also tranquillity of the soul. ${ }^{44}$

These differences between the four schools are partially reflected in Ficino's account of ethical virtues in "De virtutibus moralibus". Ficino uses the definition of virtue given in Gorgias 506e, where Plato had defined the ethical virtue (aretê) of each thing as its internal order (taxis); 'virtue' in this passage of the Gorgias, however, is not necessarily restricted to the ethical meaning; it may also comprise the ontological meaning of 'power'.

42 Ficino, De amore I.2, ed. Laurens, 7.11 [ed. Marcel, 137.14].

43 Ficino dated the "De virtutibus moralibus" to 1457 , but he did not date the other text; here I rely on Kristeller, Supplementum, vol. 1, CXXXIX.

44 Ficino, "De quatuor sectis philosophorum", 8-10. 
In the case of man, this means that his or her soul should be ordered, still according to Plato; Ficino affirms this idea in his commentary on the Gorgias. ${ }^{45}$ In the "De virtutibus moralibus", Ficino claims that Platonists, Peripatetics, Cynics and Stoics have interpreted this idea abut the soul's order differently, and that they, given their respective understanding of this order, have defined moral disposition (our habitus) differently. ${ }^{46}$

\section{Ficino's De amore: Textually and Conceptually Independent from Plato's Symposium}

Plato's Symposium is dedicated to the theme of eros or love (Gr. erôs), in the course of which Plato discusses ethical virtue. The term 'virtue' occurs prominently in the first speech, presented by Phaedrus, who concludes his speech with the following words:

So there is my description of Love (erôs) - that he is the most venerable and valuable of the gods, and that he has sovereign power to provide all virtue (aretê) and happiness (eudaimonia) for men whether living or departed. ${ }^{47}$

45 The definition of virtue in Gorgias 506e is the culmination of a long discussion with Callicles, initiated ibid., 481b; Callices states his position in 492c. In Gorgias 507a-b, Plato argues that this order is ensured by means of the virtue self-control (sôphrosynê), which in turn produces three other virtues, namnely justness, piety and courage. Ficino, In Gorgiam, in id., Opera, 1318-1319, esp. 1318.40-41.

46 Ficino, 'De virtutibus moralibus', 1.

47 Plato, Symposium 180b6-8, trans. Lamb. 
The qualification at the end of the sentence, "whether living or departed" (zôsi kai teleutêsasin), is worth observing. Plato has Phaedrus applying the notion of virtue to two phases in the cycle of the human soul, as Plato explains the cycle in the Phaedo, namely (a) the period in which the soul is incarnated in a mortal body, and (b) the soul's life after death and before its reincarnation. ${ }^{48}$

The second speaker in the Symposium, Pausanias, picks up on Phaedrus' proposal, to connect the discussion of erôs with the discussion of aretê, as indicated in the Appendix. The physician Eryximachus, presenting the third speech, and the poet Aristophanes, presenting the fourth speech, do not refer to virtue at all. The fifth speaker, Agathon, mentions briefly the four cardinal virtues when discussing the 'virtue' of Eros. However, the term 'virtue' features prominently in the sixth speech, that of Socrates, whose report of Diotima's speech represents the culmination of the entire dialogue. Socrates' answer is that eros should be understood as the soul's ascent towards the divine, that is, the good and the beautiful, whereby the soul itself becomes godlike. The seventh speech, by the drunk playboy Alcibiades, only refers to the term once and in passing, which hardly comes as a surprise.

If we compare Plato's use of the Greek term for virtue with Ficino's use of the corresponding Latin term virtus, in his commentary on Plato's Symposium, we find some notable discrepancies. Ficino does not comment on Plato's statements about virtue in the first three speeches in the Symposium (178a-189c), presented by Phaedrus, Pausanias and Eryximachus. This is remarkable: in the Symposium, the first two speakers - Phaedrus and Pausanias - made quite substantial claims about virtue and its significance to love. In $D e$

48 Id., Phaedo 69e-77a. 
amore Ficino has Giovanni Cavalcanti commenting these three speeches. However, Phaedrus' significant introduction of the theme of virtue in the context of love as a god is not reflected in the three speeches assigned to Cavalcanti in Ficino's commentary. Ficino dedicates De amore to Cavalcanti and praises him as a "hero" - a significant appellation; in the ancient Platonic tradition it denotes a being existing midway between men and God. ${ }^{49}$ The reader is certainly led to believe that the hero Cavalcanti is a virtuous man, but in $D e$ amore Ficino does not use the Cavalcanti figure to present a philosophical theory about ethical virtue.

Ficino offers a substantial and philosophical introduction of the concept of virtue in the fourth speech, delivered by Cristoforo Landino, commenting on the fourth speech in the Symposium, held by Aristophanes. Here Landino presents a theory of virtue drawing on a light metaphysics: The soul's virtues are acquired by means of God's infusion of his splendour (splendor) or light (lux/lumen). In Plato's Symposium, on the other hand, Aristophanes did not use the term for virtue at all. Nor did he use the imagery of infused light.

Ficino does attribute various virtues to eros as a god, namely through Carlo Marsuppini's speech, the fifth speech, but merely as a literary device. In the corresponding fifth speech in the Symposium, Plato had the young Agathon presenting a literary image of the personified Eros and his virtues, including his cardinal virtues; Ficino picks up on this

49 Id., Symposium 179b, refers to the hero as someone infused with eros. See also Iamblichus, De mysteriis I.3, I.5, II.1-6, ed. des Places, 42-3, 47-8, 77-87. Ficino latches on to this meaning of hero in his Theologia platonica XIV.8.2 and XVII.3.2, eds Hankins, Bowen et alii, vol. 4, 280, and vol. 6, 28-30. Moreover, he refers to Cavalcanti as 'heoric' in some of his letters to him; see Ficino, Epistulae 29, 30, 31, ed. Gentile, $61,63,64$. 
when he has Carlo Marsuppini commenting on Agathon's speech. However, Marsuppini does not develop this pretext into a philosophical theory.

Plato's most important speech in the Symposium, Diotima's speech reported by Socrates in the sixth speech of the Symposium, offers several statements about virtue and its significance to the noetic ascent, which is paramount to the philosopher, and which is repeated elsewhere in his dialogues. ${ }^{50}$ In De amore, Ficino has Tommaso Benci presenting a philosophically elaborate theory of moral and intellectual virtues, which does not rely on Plato's Symposium, but which owes much to Aristotle's ethics. According to Benci, moral virtues are acquired through upbringing, education and exercise, and the possession of moral virtues is the precondition for acquiring the intellectual virtues. ${ }^{51}$

\section{Ethical Virtues in Our Souls and in God}

In De amore, Cristoforo Landino is given the task of commenting upon the poet Aristophanes' speech (Symposium 189c-194e). As stated above, the question dealt with in the Symposium is the nature of eros or love (erôs), and Aristophanes' speech discusses the myth about the first hermaphroditic being that originally possessed three sexes, man, woman and a mixture of the two, the man-woman. The strength and vigour of these

50 See the references in note 40 above.

51 Ficino, De amore VI.18, ed. Laurens, 199.28-201.22 [ed. Marcel, 237.20-238.13]. Aristotle, Ethica nicomachea I.13 1103 1 1-10, distinguished between moral and intellectual virtues. Moral virtues are explained ibid. II.1-7 1103 $15-1108^{\mathrm{b}} 10$, intellectaul virtues ibid. VI.1-3 1138 18 -1140 30 . Ibid., II.4, Aristotle assigns to exercise and habit an important role in the formation of moral virtues. It should be observed, however, that exercise is similarly assigned an important role in Plato's ethics, e.g. Plato, Gorgias 524d-e, 526c, 527d. 
hermaphroditic beings made them conspire against the gods. The gods sliced them into two sexes, man and woman, in order to make them weaker and in order to make them seek their counterpart and generate offspring and multiply: Their sexual desire is to be understood as their striving to regain the lost unity. Hence the two sexes and their sexual desire remind us about the early fall of man. Moreover, Aristophanes explains, if these divided beings dare to conspire against the gods again, they would be sliced again.

Landino interprets the myth in cognitive terms. It is about the human soul and its early fall. Human souls had originally been given two lights by the divinity, one innate and one infused - the innate light allowing human souls to understand things in the lower world, that is, the sensible world, and the infused light allowing human souls to understand the higher world. The human souls became self-sufficient and haughty (superbiores) in their striving to become equal with God, in the process of which they relied exclusively on their own innate light; at that point they lost their infused light that originally allowed the souls to comprehend the higher world. If these souls rely too much on their innate light, they will be punished once again, and this time they will even lose their innate light, Landino explains. ${ }^{52}$

However, these souls do not regain their lost, original unity of innate and infused light by regaining lost cognitive categories, but by assimilating ethical ones, as Landino argues in IV.2, IV .5 and IV.6. ${ }^{53}$ One key passage from IV.2, explaining the infused light, reads as follows:

\footnotetext{
52 Ibid., IV.2, ed. Laurens, 69.4-13 [ed. Marcel, 169.12-3].

53 Ibid., IV.2, IV .5, IV .6, ed. Laurens, 69.14-19, 77.14-29, 79.8-15, 79.23-7, 83.12 [ed. Marcel, 169.22-27, $173.26-174.13,174.33-175.2,175.10-14,176.28-9]$.
} 
Some received the splendour [fulgor] of God as courage, which is male; others as temperance, which is female; others as justice, which is mixed. These three virtues in us are the daughters of three others, which God possesses. But in God those three are called sun, earth, and moon; but in us male, female, and mixed. ${ }^{54}$

These three ethical virtues in the human soul (courage, temperance and justice) are to be seen as a reduplication of the same three virtues in God. These three virtues represent the three sexes in Aristophanes' myth about man's early fall.

As mentioned already, in Aristophanes' myth, the original hermaphroditic being had in fact not two but three sexes: man, woman and a third sharing characteristics of the two other, namely the man-woman (189d-190c). In Aristophanes' account, the male was originally the offspring of the sun, the female of the earth, and the third, made up of both sexes, of the moon (190d). In the above quote Landino assigns ethical virtues to these three sexes: man, corresponding to the sun, is assigned courage; woman, corresponding to the earth, is assigned temperance; and the man-woman, corresponding to the moon, is assigned justice. ${ }^{55}$ Although Aristophanes had not elaborated such claims about virtues in $189 \mathrm{c}-194 \mathrm{e}$,

54 Ficino, De amore IV.2, ed. Laurens, 69.14-19 [ed. Marcel, 169.22-7], trans. Jayne. (Ficino, Dell'amore IV.2.10-11, ed. Niccoli, 61, follows the Latin text, using 'virtù' for 'virtutes'.) Landino repeats this theory twice in his speech, in keeping with the literary pretext in Plato's Symposium: Ficino, De amore IV.5, ed. Laurens, 79.8-15, 79.23-7 [ed. Marcel, 174.33-175.2, 175.10-14].

55 Ficino repeats this scheme in De amore IV.5, ed Laurens, 79.8-15 [ed. Marcel, 174.33-175.2] 
Landino's three virtues mentioned (courage, temperance, justice) fitted into the literary framework, Aristophanes' myth about the two sexes and their origin.

Why is the last of the four cardinal virtues, prudence, not mentioned? Is there any reason apart from the trivial one that Aristophanes' myth requires something that one can divide into three? Ficino may have excluded prudence because it simply shows the individual soul what bliss $i s$, whereas the exercise of three other virtues (courage, temperance, justice) actually lead to bliss; as is made clear in IV .5, God guides the exercise of these three virtues through prudence. ${ }^{56}$

What is the source to the idea that ethical virtues in the human soul also exist in God? The fourth speech in Plato's Symposium, which Landino comments upon, did not advance a theory of ethical virtue at all, as indicated in the Appendix. In general, Plato had not claimed in the Symposium that the ethical virtues in the human soul are reduplicated in God. However, the reduplication of the virtues feature Plato's Republic VI 500c-e, where it is claimed that a human being may turn inwardly towards that which is eternal and unchanging, imitating the patterns found there; in this way he or she fashions him- or herself in the likeness of these patterns and becomes ordered. This is a cognitive process that has implications for the domain of ethics, since the ethical virtues temperance (sôphrosynê), justice (dikaiosynê) and other "civic virtues" (dêmotikai aretai) are fashioned in this manner. This interpretation of Plato's ethics would to some extent fit into Ficino's definition of the Platonic notion of virtue in his early treatise "De virtutibus moralibus": here 'virtue' was defined on the basis of Gorgias as the soul's internal order, as explained above. In his Gorgias 507a-b, Plato had argued that this order is ensured by means of the

56 Ibid., IV.5, ed. Laurens, 77.14-29 [ed. Marcel, 173.26-174.13]. Ficino affirms his ethical pluralism ibid., IV.5, ed. Laurens, 79.23-7 [ed. Marcel, 175.10-14]; id., Epistulae 115.220-2, ed. Gentile, 208-209. 
virtue temperance (sôphrosynê), which in turn produces three other virtues, namely justice, piety and courage. Ficino embraced that idea in his commentary to Plato's Gorgias. ${ }^{57}$

In addition to Plato himself, Plotinus' Ennead I is also a possible source. Ennead I.2 provides an explanation of Plato's Theaetetus 176a-b, where it is stated that the human soul should become similar to the divine: Plotinus argues that this should be understood as the soul's assimilation of the higher virtues, existing in the hypostasis nous. Ficino's reduplication of the virtues in De amore IV.2 and IV .5 is reminiscent of Plotinus' Ennead I.2.6.13-18, where it is claimed that the exemplary virtues exist in the hypostasis nous as models or paradigms (in Greek paradeigmata), and that the virtues in the human soul originate from these paradeigmata: ${ }^{.8}$

There are two kinds of wisdom, one in intellect [nous], one in soul [psychêe]. That which is There [in intellect] is not virtue, that in the soul is virtue. What is it, then There? The act of the self, what it really is; virtue is what comes Thence and exists here in another. For neither absolute justice nor any other moral absolute is virtue, but a kind of exemplar [paradeigma]; virtue is what is derived from it in the soul. ${ }^{59}$

57 Ficino, In Gorgiam, in id., Opera, 1318-1319, esp. 1318.40-1.

58 Plotinus, Enneads I.2.6.17 and I.2.7.3. Plotinus must have thought of these paradeigmata as important to his ethics, since he returns to them immediately afterwards (Enneads I.2.7.)

59 Plotinus, Enneads I.2.6.13-18 (trans. Armstrong). For Ficino's Latin translation, see Plotinus, Opera, trans. Ficino, 15. 
Plotinus develops this idea in the remaining part of Ennead I.2.6 and in I.2.7, and it is an integral part of his metaphysics and his psychology. It is worth observing that Ficino in his commentary to Plotinus' Ennead I.2, especially I.2.6 and I.2.7, largely affirmed this Plotinian theory, speaking of the paradeigmata as exemplares.$^{60}$ Plotinus is thus a possible source for the De amore IV.2 and IV.5, since we find the idea about virtues in the human soul as a reduplication of the same virtues in God. However, since Ficino does not refer explicitly to any source, and since I have not been able to find verbal similarities between the cited passages in De amore IV and ancient ethical texts, the suggested sources - Plato and Plotinus - remain nothing but possible sources. ${ }^{61}$

60 Ficino, In Plotinum I.2.6 and I.2.7, in Plotinus, Opera, trans. Ficino, 10-11.

61 Compare my suggestion with modern commentators, who have not pointed out Plato, Republic 500c-e or Plotinus, Ennead I.2 as possible sources. We find Ficino's theory about the assimilation of a lost unity of innate and infused light by means of etical virtues in his De amore IV.2, IV .5, IV.6, ed. Laurens, 69.1419, 77.14-29, 79.8-15, 79.23-7, 83.12 [ed. Marcel, 169.22-7, 173.26-174.13, 174.33-175.2, 175.10-14, 176.28-9]. Marcel did not point out sources to any of these passages in his edition and translation of 1956. In 1984, Blum did not indicate a source for any of these passages in De amore. In his note to VI.18, however, he pointed out Aristotle, Ethica nicomachea I.13 $1103^{\mathrm{a}} 3 \mathrm{ff}$. when accounting for the dinstiction between moral and intellectual virtues. In 1985, Jayne identified sources to one of these passages in De amore, namely IV .5, 77.14-29: It draws upon four groups of sources, including Plato, Aristotle, Cicero, Aquinas and Plotinus (Ennead I.6); the sources suggested in this article (Plato, Republic VI 500c-e and Plotinus, Ennead I.2), are not listed; see Jayne's note in Ficino, Plato's Commentary on Love, IV.5, 77. In 2002, Laurens suggested sources for two of these passages: For IV.2, ed. Laurens, 69.14-19, he pointed out the four classical cardinal virtues according to their hierarchy among Christian thinkers, though without mentioning any specific author; for IV.5, ed. Laurens, 77.14-29, he refered to VI.18 and its division between moral and intellectual virtues, pointing out that they derive from Aristotle, Ethica nicomachea I.13 $1103^{\mathrm{a}} 3 \mathrm{ff}$, thus following Blum. 
It is worth observing, however, that in De amore Ficino avoided the rendering of Plotinian virtue theory which could be found in Macrobius' In somnium Scipionis I.8, and which had been known in the medieval period. Ficino's intention may not only have been to return to the authentic source to this idea, perhaps Plato's Republic VI 500c-e or Gorgias 506e, or possibly Plotinus' Ennead I.2, but also to steer free of Aquinas' appropriation of this ancient virtue theory. Ficino did not reserve the ascent to the virtues in God to those who were blessed in this life, e.g. the saints, nor did he reserve it for those who were infused with virtues by divine grace, or those having leisure and dedication for learning. This late medieveal appropriation of Macrobius' In somnium Scipionis I.8, found in Aquinas, has a monastic ring to it, which Ficino steered free of with his explanation of virtue in De amore IV.2 and IV.5. In sociological and institutional terms, his ethical scheme opened up for "access" to the virtues in God for groups of people who did not belong to religious orders and who did not necessarily enjoy the leisure to approach the divine thorugh contemplation and learning: it was open to all groups of human beings, due to their natural constitution and their implanted spark - all human beings who had the desire and will to approach the divine. As we shall see below, the soul's actual acquisition of these virtues in God did not depend upon God's grace, or contemplation alone.

\section{The Soul's Acquisition of Ethical Virtues, and the Role of God}

Three issues are not yet clear: First, how should a human being acquire and assimilate the virtue(s) sought after? Second, what should motivate a human being to seek what it has lost - the infused light and its corresponding ethical virtue - especially if the being in 
question can do with the innate light alone? Third, what is the role of God in this process?

De amore IV.5 provides some answers to these questions:

But when God infused His own light $[l u x]$ into the soul, He adapted the light above all to this: that it might lead men to bliss, which consists in the possession of Him. To this we are led by four virtues: Prudence, Courage, Justice, and Temperance.

Prudence first shows us bliss; those other three virtues, like three paths, lead to bliss. And so God tempers his own spark [scintilla] variously in various souls to this end, that under the direction of Prudence some seek their author again through the offices of Courage, others through the offices of Justice, and others through the offices of Temperance. Certainly some, thanks to this gift, undergo dangers and death with a brave heart, for the worship of God, for integrity, or for fatherland. Others arrange life so justly that they neither themselves do harm to anyone nor, insofar as possible, permit it to be done by others. Others master the appetites by vigil, fast, and work. These certainly proceed by three paths, but they all strive to arrive at the same end of bliss which Prudence shows them. Accordingly those three virtues are also contained in the Prudence of God himself. Enflamed with a desire for them, the souls of men seek to arrive at them, by exercising them, and then to cleave to them and possess them eternally. ${ }^{62}$

${ }_{62}$ Ficino, De amore IV.5, ed. Laurens, 77.14-29 [ed. Marcel, 173.26-174.13]. Eng. trans., Jayne, 77. (Ficino, Dell'amore IV .5.7-13, ed. Niccoli, 68, follows the Latin text.) 
As in the earlier quotation from IV.2, Ficino connects the concept of virtue with the concept of light: In IV.2, Ficino referred to fulgor, the spendour of God, whereas he refers to the lux, the light of God, in IV.5. ${ }^{63}$ How should we understand these terms? The Latin term lux is to be distinguished from the Latin terms fulgor and splendor; lux denotes a light source, whereas the fulgor or splendor denotes the shining produced by a light source. Ficino points out this characteristic of lux in De amore VI.17: Lux is like the sun itself, which is a source of light, whereas splendor is to be understood as the brightness produced by that light source..$^{64}$

Now let me return to the three questions posed at the outset of this section. As regards the first question, the acquisition of the lost light and the adjunct ethical virtue, Landino explains in this quote that four elements are required: (1) God's infused light (lux); (2) the spark (scintilla) in the individual human soul - a spark that is tempered by God, causing a plurality of virtues in different souls; (3) the individual human being's practice of the virtue to be acquired, where prudence directs the suitable practices training their corresponding virtues, i.e. courage, justice and temperance; and (4) the soul's desire (desiderium) for these virtues.

${ }^{63}$ Ficino, De amore IV.5, ed. Laurens, 79.23-7 [ed. Marcel, 175.10-14], also refers to the infused light in an ethical context. The notion of the infused light (lux infusa) is also to be found in Ficino's letter to Paolo Orlandini (dated 1496), in Ficino, The Philebus Commentary, 487-9.

${ }^{64}$ Ficino, De amore VI.17, ed. Laurens, 193.32-5 [ed. Marcel, 234.25-8]. Plato, Republic VI 506b-509c and Plotinus, Enneads V.1.6.28-40, are probably the ultimate sources to Ficino's notion of light. The distinction between lux and splendor/fulgor, however, may be mediated by medieval authors such as Augustine (e.g. De civitate dei VIII.9-10), Bonaventure and others. For the complex and long tradition of lux and fulgor/lumen, see Mathieu et alii, 'Lumière'. 
The elements (3) and (4) are subjected to human will, and by means of (3) Landino argues for the value of the active life; the desire for the virtues in God and the contemplation of these virtues in God are necessary but not sufficient, since the virtues in question are only fully assimilated when translated into practice. Hence, the virtues are acquired through moral agency. The motivation in the moral agent consists in the search for bliss, attained through the practice of these virtues (question two).

Let me move on to the third question, the role of God in this process of regaining lost ethical categories. God's infusion of light is seen as a precondition for human beings' display of these virtues in their moral actions: If God's light (lux), and its adjunct virtues in God, had not been infused into the human soul, and if this soul had no tempered spark (scintilla) implanted that could be enflamed and thus motivate the soul to strive, then there would be no moral perfection, according to Landino; the exercise of virtuous actions would not in itself bring about such a moral perfection, since it would lack this metaphysical and psychological precondition.

\section{Conclusion}

The composition of Ficino's De amore proved congenial to his ethical agenda, stressing emulation of worthy exempla rather than abstract theorizing. On a philosophical level, his familiarity with the original sources of late ancient Platonism and its ethics, Plotinus in particular, allowed him to bypass the late medieval appropriation of this tradition as it had taken place through Macrobius' In somnium Scipionis; it allowed Ficino to advance an alternative and more secular interpretation of late Platonic ethics through Landino's fourth speech in De amore. 
Through Landino, Ficino thus balanced two concerns. On the one hand, he remains loyal to Plato's and Plotinus' idea that the source of ethical virtue is of a transcendent nature, accessible to human beings through contemplation (Plato, Republic 500d-e; Plotinus, Ennead I.2.6-7). On the other hand, he wants to steer free of an intellectualism, typified in the Platonic spoudaios, that might easily denigrate the value of vita activa, and he similarly wants to steer free of Aquinas' restriction of the enjoyment of virtues in God to those living a withdrawn and religious life, far removed from the vita activa. Ficino's view would probably have appealed to the readers of De amore, counting Florentine aristocrats, men of letters and businessmen like the Medici, many of whom were intensively engaged in the vita activa. In so far as they enjoyed the vita contemplativa, and they certainly did, they rarely did so within the framework of religious orders. In this way Ficino's interpretation of Plotinus' ethics was instrumental to the shaping of modern ethics. 


\section{Appendix. 'Virtue' in Plato's Symposium and in Ficino's De amore}

\begin{tabular}{|c|c|c|c|}
\hline $\begin{array}{l}\text { Speeches in Plato's } \\
\text { Symposium: }\end{array}$ & $\begin{array}{l}\text { The term aretê in } \\
\text { Plato's Symposium }\end{array}$ & $\begin{array}{l}\text { Speeches in Ficino's De } \\
\text { amore }\end{array}$ & $\begin{array}{l}\text { Ficino's use of the term } \\
\text { virtus in De amore }\end{array}$ \\
\hline $\begin{array}{l}\text { 1. Phaedrus 178a- } \\
180 \mathrm{~b}\end{array}$ & 179a8, 179d1, 180a8 & I.2-4: Giovanni Cavalcanti & I.2-4: No use of the term. \\
\hline $\begin{array}{l}\text { 2. Pausanias 180b- } \\
185 \mathrm{e}\end{array}$ & $\begin{array}{l}184 \mathrm{c} 3,184 \mathrm{c} 6,184 \mathrm{~d} 1, \\
184 \mathrm{e} 1,185 \mathrm{~b} 1,185 \mathrm{~b} 2 \\
185 \mathrm{~b} 5,185 \mathrm{~b} 7\end{array}$ & $\begin{array}{l}\text { II.1-9: Antonio degli Agli, } \\
\text { Bishop of Fiesole, leaves } \\
\text { the speech to Cavalcanti }\end{array}$ & II.1-9: No use of the term. \\
\hline $\begin{array}{l}\text { 3. Eryximachus } \\
185 \mathrm{e}-189 \mathrm{c}, \\
\text { physician }\end{array}$ & No use of the term & $\begin{array}{l}\text { III.1-4: Ficino, the } \\
\text { physician, leaves the speech } \\
\text { to Cavalcanti }\end{array}$ & III.1-4: No use of the term. \\
\hline $\begin{array}{l}\text { 4. Aristophanes } \\
189 \mathrm{c}-194 \mathrm{e}, \text { poet }\end{array}$ & No use of the term & $\begin{array}{l}\text { IV.1-6: Cristoforo Landino, } \\
\text { poet }\end{array}$ & $\begin{array}{l}\text { In IV.1-6, the term virtus is } \\
\text { used in IV.2, p. 69.13-18; } \\
\text { IV .5, p. } 77.14-29 \text {; IV .5, p. } \\
79.8-15 \text {; IV .5, p. } 79.23-27 \text {; } \\
\text { IV .6, p. } 83.12\end{array}$ \\
\hline $\begin{array}{l}\text { 5. Agathon 194e- } \\
\text { 201d, young man }\end{array}$ & $\begin{array}{l}\text { 196b5 [explained in } \\
196 \mathrm{~d} 4-5 \text { by means of } \\
\text { the four cardinal } \\
\text { virtues] }\end{array}$ & V.1-13: Carlo Marsuppini & $\begin{array}{l}\text { In V.1-13, the term virtus is } \\
\text { used in V.1, p. } 85.27-28 ; \mathrm{V} .8 \text {, } \\
\text { pp. 113.1-115.28 }\end{array}$ \\
\hline $\begin{array}{l}\text { 6. Socrates } \\
\text { (Diotima) 201d- } \\
212 d\end{array}$ & $\begin{array}{l}208 \mathrm{~d} 6,208 \mathrm{~d} 7,209 \mathrm{a} 4, \\
209 \mathrm{~b} 8,209 \mathrm{e} 3,212 \mathrm{a} 4, \\
212 \mathrm{a} 5\end{array}$ & VI.1-19: Tommaso Benci & $\begin{array}{l}\text { In VI.1-19, the term virtus is } \\
\text { used in VI.18, p. 199.23-24; } \\
\text { VI.18, pp. 199.28-201.14 }\end{array}$ \\
\hline $\begin{array}{l}\text { 7. Alcibiades 212d- } \\
223 d\end{array}$ & $222 \mathrm{a} 4$ & $\begin{array}{l}\text { VII.1-17: Cristoforo } \\
\text { Marsuppini }\end{array}$ & VII.1-17: No use of the term. \\
\hline
\end{tabular}




\section{BIBLIOGRAPHY}

\section{Primary sources}

Alcinous [Alcinoos], $\Delta \downarrow \delta \alpha \sigma x \alpha \lambda \iota x o ́ s$, in id., Enseignement des doctrines de Platon, Greek and French text, introduction, edition and notes by John Whittaker, French translation by Pierre Louis. Paris: Les Belles Lettres, 1990.

Aristotle, Ethica nicomachea, Greek text edited by Ingram Bywater. Clarendon: Oxford, 1890.

Ficino, Marsilio. Opera, 2 vols with continuous pagination. S. Henricpetri: Basel, 1576. Anastatic reprint: Edited by Stéphane Toussaint, 2 vols. Paris: Phénix Éditions, 2000.

Ficino, Marsilio. Commentarium in Convivium Platonis, de amore, in Ficino, Commentaire sur le Banquet de Platon, Latin and French text, edition, translation and introduction by Raymond Marcel. Paris: Les Belles Lettres, 1956. Cited as Ficino, De amore, ed. Marcel.

Ficino, Marsilio. Commentarium in Convivium Platonis, De amore, in M. Ficino, Commentaire sur Le Banquet de Platon, De l'amour, Latin text, French translation and notes by Pierre Laurens. Paris: Les Belles Lettres, 2002. Cited as Ficino, De amore, ed. Laurens.

Ficino, Marsilio. El libro dell'amore, edited by Sandra Niccoli. Florence: L. S. Olschki, 1987.

Ficino, Marsilio. Commentary on Plato's Symposium on Love. English translation, introduction and notes by S. R. Jayne. Woodstock, Connecticut: Spring Publications, 1985. 
Ficino, Marsilio. Über die Liebe oder Platons Gastmahl [1914], Latin and German text, German translation by Karl Paul Hasse, notes by Paul Richard Blum [1984]. Hamburg: Felix Meiner, 1984. I cite the reprint from 1994.

Ficino, Marsilio. Kommentar til Platons Symposion, eller Om eros, Danish translation, introduction and notes by Leo Catana. Copenhagen: Museum Tusculanum Forlag, 2013.

Ficino, Marsilio. The Philebus Commentary, Latin text and English translation and notes by Michael J. B. Allen. Berkeley: University of California Press, 1975.

Ficino, Marsilio. Le lettere, vol. 1, edited by Sebastiano Gentile. Florence: L. S. Olschki, 1990. I cited this work as 'Ficino, Epistuae'.

Ficino, Marsilio. In Plotinum. See Plotinus, Operum philosophicorum omnium libri LIV.

Ficino, Marsilio. Theologia platonica, in id., Platonic Theology, 6 vols, Latin text by James Hankins, William Bowen et alii, English translation by Michael J. B. Allen, John Warden et alii. Cambridge, Mass. and London: Harvard University Press, 2001-2006.

Ficino, Marsilio. "De virtutibus moralibus”, in Kristeller, Supplementum, vol. 2, 1-6.

Ficino, Marsilio. “De quatuor sectis philosophorum”, in Kristeller, Supplementum, vol. 2, 711.

Ficino, Marsilio. “Argumentum de summo bonum”, in Kristeller, Supplementum, vol. 2, 9697.

Iamblichus, De mysteriis Aegyptorum, edited by Eduoard des Places. Paris: Les Belles Lettres, 1989. 
Macrobius, In somnium Scipionis, 2 vols. Latin and French text, edited, translated and with notes by Mirielle Armisen-Marchetti. Paris: Les Belles Lettres, 2003.

Peter Abelard, Theologia christiana, in id., Opera theologica, edited by Eligius M.

Buytaert and Constant J. Mews. Corpus christianorum, vol. 12. Turnholt: Brepols, 1969.

Plato. Opera, edited by John Burnet, 5 vols. Oxford: Clarendon, 1900-1907.

Plotinus, Operum philosophicorum omnium libri LIV in sex enneades distributi, Greek and Latin text, edited, translated and commented by Marsilio Ficino. Basel: P. Perna, 1580. Anastatic reprint with an intro. by Sthépane Toussaint: Enghien-les-Bains: Les Éditions du Miraval, 2008. I cite this work as 'Plotinus, Opera, trans. Ficino'.

Plotinus. Opera, edited by Paul Henry and Hans-Rudolf Schwyzer, 3 vols. Oxford: Clarendon, 1964-1982. Cited as 'Plotinus, Enneads'.

Porphyry. Sententiae, in id., Sentences, 2 vols, edited and translated by Luc Brisson. Paris: Vrin, 2005, vol. 1, 308-378.

Thomas Aquinas. Summa theologiae, 59 vols, edited by Michael Browne, Aniceto Fernandez et al. London and New York: Blackfriars, 1963-1975.

\section{Secondary sources}

Armisen-Marchetti, Mirielle. "Introduction”, in Macrobius, In somnium Scipionis, 2 vols. Latin and French text, edition, translation and notes by Mirielle. Armisen-Marchetti. Paris: Les Belles Lettres, 2003, VII-XCVII.

Blum, Paul Richard. For Blum's notes, see Ficino, Über die Liebe oder Platons Gastmahl. 
Blum, Paul Richard. “The Young Paul Oskar Kristeller as a Philosopher”, in Kristeller Reconsidered. Essays on his Life and Scholarship, edited by John Monfasani. New York: Italica Press, 2006, 19-38.

Brisson, Luc. "The Doctrine of the Degress of Virtues in the Neoplatonists. An Analysis of Porphyry's Sentence 32, its Antecedents and its Consequences", in Reading Plato in Antiquity, edited by Harold Tarrant and Dirk Baltzly. London: Duckworth, 2006, 89-106.

Bücher, Christian Friedrich. Plato mysticus in pietista redivivus. Dantzig: Simon Reinigern, 1699.

Cassirer, Ernst. 'Giovanni Pico della Mirandola. A Study in the History of Renaissance Ideas'. Journal of the History of Ideas 3 (1942): 123-144, 319-346.

Catana, Leo. The Historiographical Concept 'System of Philosophy': Its Origin, Nature, Influence and Legitimacy. Leiden and Boston: Brill, 2008.

Catana, Leo. 'Changing Interpretations of Plotinus: The 18th-Century Introduction of the Concept of a 'System of Philosophy'. The International Journal of the Platonic Tradition 7, no. 1 (2013): 50-98.

Catana, Leo. 'Thomas Taylor's Dissent from Some 18th-Century Views on Platonic Philosophy: The Ethical and Theological Context'. The International Journal of the Platonic Tradition 7, no. 2 (2013): 180-220.

Celenza, Christopher. 'What Counted as Philosophy in the Italian Renaissance? The History of Philosphy, the History of Science, and Styles of Life'. Critical Inquiry 39, no. 2 (2013): 367-401.

Dress, Walter. Die Mystik des Marsilio Ficino. Berlin and Leipzig: De Gruyter, 1929. 
Emilsson, Eyjólfur Kjalar. 'Porphyr': Stanford Encyclopedia of Philosophy. Consulted on November 29, 2009.

Flamand, Jean-Marie. “Éditions et traductions des AФOPMAI de Porphyre”, in Porphyry, Sententiae, in id., Sentences, 2 vols, edited and and translated into French by Luc Brisson. Paris: Vrin, 2005, vol. 1, 285-300.

Gentile, Sebastiano, Sandra Niccoli, and Paolo Viti (eds). Marsilio Ficino e il ritorno di Platone. Manoscritti stampe e documenti 17 maggio - 16 giugno 1984, edited by Sebastiano Gentile, Sandra Niccoli, and Paolo Viti, preface by Eugenio Garin. Florence: Casa Editrice Le Lettere, 1984.

Hankins, James. Plato in the Italian Renaissance, 2 vols with continuous pagination. Leiden, etc.: Brill, 1990.

Hankins, James. "Kristeller and Ancient Philosophy”, in Kristeller Reconsidered. Essays on his Life and Scholarship, edited by John Monfasani. New York: Italica Press, 2006, 131-138.

Hochschild, Joshua P. "Porphyry, Bonaventure and Thomas Aquinas: A Neoplatonic Hierarchy of Virtues and Two Christian Appropriations", in Medieval Philosophy and the Classical Tradition in Islam, Judaism and Christianity, edited by John Inglis. Abingdon: Routledge, 2002, 245-259.

Inglis, John. 'Aquinas's Replication of the Acquired Moral Virtues: Rethinking the Stadard Philosophical Interpretation of Moral Virtue in Aquinas'. Journal of Religious Ethics 27, no. 1 (1999): 3-25. 
Jayne, Sears. “Introduction”, in Ficino, Commentary on Plato’s Symposium on Love. English translation, introduction and notes by Sears Jayne. Woodstock, Connecticut: Spring Publications, 1985, 1-32.

Karamanolis, George. 'Transformations of Plato's Ethics: Platonist Interpretations of Plato's Ethics from Antiochus to Porphyry'. Rhizai 1 (2004): 73-105.

Kraye, Jill. "Moral Philosophy", in The Cambridge History of Renaissance Philosophy, edited by Charles B. Schmitt, Quentin Skinner, Eckhard Kessler and Jill Kraye. Cambridge: Cambridge University Press, 1988, 303-386.

Kristeller, Paul Oskar. Der Begriff der Seele in der Ethik des Plotin. Tübingen: J. C. B. Mohr, 1927.

Kristeller, Paul Oskar. Supplementum ficinianum. Marsilii Ficini Florentini philosophi platonici opuscula inedita et dispersa, edited by Paul Oskar Kristeller, 2 bind. Florence: Olschki, 1937.

Kristeller, Paul Oskar. The Philosophy of Marsilio Ficino, English translation by Virginia Conant. New York: Columbia University Press, 1943.

Kristeller, Paul Oskar. "Francesco da Diacceto and Florentine Platonism in the Sixteenth Century”, in Miscellanea Giovanni Mercati, IV. Vatican City, 1946, 260-304. Reprint: id., Studies in Renaissance Thought and Letters, vol. 1. Rome: Storia e letteratura, 1956, 287-336.

Kristeller, Paul Oskar. “A Thomist Critique of Marsilio Ficino’s Theory of Will and Intellect. Fra Vincenzo Bandello da Castelnuovo O.P. and his Unpublished Treatise Addressed to Lorenzo de' Medici”. In Harry A. Wolfson Jubilee Volume (English Section), vol. 2. Jerusalem: American Academy for Jewish Research, 1965, 463-494. 
Kristeller, Paul Oskar. “The Place of Ethics in Renaissance Thought”, in id., Studies in Renaissance Thought and Letters II. Rome: Storia e letteratura, 1985, 167-184.

Kristeller, Paul Oskar. 'Neoplatonismo e Rinascimento'. Il veltro, vol. 35 (1991): 25-37.

Kristeller, Paul Oskar. Filosofi greci dell'età ellenistica. Pisa: Scuola Normale Superiore, 1991.

Lieshout, Henri van. La théorie Plotinienne de la vertu. Paderborn: Bonifacius-Druckerei, and Paris: Librarie des jeunes, 1926.

Mathieu, Domnique, et alii, 'Lumière', in Dictionnaire de spiritualité. Ascétique et mystique. Doctrine et histoire, 17 vols., eds Marcel Viller, F. Cavallera and J. de Guibert Paris: Gabriel Beauchesne et ses fils, 1937-1995, vol. 9, cols 1142-1183.

Robichaud, Denis J.-J. 'Marsilio Ficino’s De vita Platonis, Apologia de moribus Platonis, Against the Poetasters and Cynics: Aristippus, Lucian, Cerberus, and Other Dogs'. Accademia. Revue de la Société Marsile Ficin, 2006/VIII: 23-59.

Saffrey, Henri D. 'Florence, 1492: The Reappearance of Plotinus'. Renaissance Quarterly 49 (1996): 488-508.

Saitta, Giuseppe. La filosofia di Marsilio Ficino. Messina: Casa editrice G. Principato, 1923.

Scheuermann-Peilicke, Wolfgang. Licht und Liebe. Lichtmetapher und Metaphysik bei Marsilio Ficino. Hildesheim etc.: Georg Olms Verlag, 2000.

Vasoli, Cesare. 'Ficino, Marsilio', in Dizionario biografico degli italiani, vol. 1-. Istituto della enciclopedia italiana: Rome, 1960-, vol. 47 (1997), 378-395.

Wolters, Albert, 'Ficino and Plotinus' Treatise On Eros', in Ficino and Renaissance 
Neoplatonism, eds Konrad Eisenbichler and Olga Zorzi Pugliese. Toronto: Dovehouse Editions Canada, 1986, 189-197.

Wolters, Albert, 'The First Draft of Ficino's Translation of Plotinus', in Marsilio Ficino e il ritorno di Platone: Studi e documenti, 2 vols, ed. Gian Carlo Garfagnini. Florence:

Olschki, 1986, vol. 1, 305-29.

Zintzen, Clemens. "Bemerkungen zur Nachwirkung des Macrobius in Mittelalter und Renaissance”, in Roma renascens. Beiträge zur Spätantike und Rezeptionsgeschichte Ilona Opelt in Verehrung gewidmet. Frankfurt am Main etc.: Peter Lang, 1988, 415-439. 